\title{
Housefly larvae hydrolysate: orthogonal optimization of hydrolysis, antioxidant activity, amino acid composition and functional properties
}

\author{
Juan Wang ${ }^{1 \dagger}$, Yansheng Wang ${ }^{1,2+}$, Xiangli Dang ${ }^{1}$, Xiaoxia Zheng ${ }^{1}$ and Wenqing Zhang ${ }^{{ }^{*}}$
}

\begin{abstract}
Background: Antioxidant, one of the most important food additives, is widely used in food industry. At present, antioxidant is mostly produced by chemical synthesis, which would accumulate to be pathogenic. Therefore, a great interest has been developed to identify and use natural antioxidants. It was showed that there are a lot of antioxidative peptides in protein hydrolysates, possessing strong capacity of inhibiting peroxidation of macrobiomolecular and scavenging free redicals in vivo. Enzymatic hydrolysis used for preparation of antioxidative peptides is a new hot-spot in the field of natural antioxidants. It reacts under mild conditions, with accurate sitespecific degradation, good repeatability and few damages to biological activity of protein. Substrates for enzymatic hydrolysis are usually plants and aqua-animals. Insects are also gaining attention because of their rich protein and resource. Antioxidative peptides are potential to be exploited as new natural antioxidant and functional food. There is a huge potential market in medical and cosmetic field as well.

Result: Protein hydrolysate with antioxidant activity was prepared from housefly larvae, by a two-step hydrolysis. Through orthogonal optimization of the hydrolysis conditions, the degree of hydrolysis was determined to be approximately $60 \%$. Fractionated hydrolysate at $25 \mathrm{mg} / \mathrm{mL}, 2.5 \mathrm{mg} / \mathrm{mL}$ and $1 \mathrm{mg} / \mathrm{mL}$ exhibited approximately $50 \%$, $60 \%$ and $50 \%$ of scavenging capacity on superoxide radicals, 1, 1-Diphenyl-2-picrylhydrazyl radicals and hydroxyl radicals, respectively. Hydrolysate did not exhibit substantial ion chelation. Using a linoneic peroxidation system, the inhibition activity of hydrolysate at $20 \mathrm{mg} / \mathrm{mL}$ was close to that of $20 \mu \mathrm{g} / \mathrm{mL}$ tertiary butylhydroquinone, suggesting a potential application of hydrolysate in the oil industry as an efficient antioxidant. The lyophilized hydrolysate presented almost $100 \%$ solubility at $\mathrm{pH} 3-\mathrm{pH}$ 9, and maintained nearly $100 \%$ activity at $\mathrm{pH} 5-\mathrm{pH} 8$ at $0^{\circ} \mathrm{C}-4^{\circ} \mathrm{C}$ and room temperature during the first 6 months of storage. Essential amino acids in the hydrolysate accounted for $43 \%$ of the total amino acids.
\end{abstract}

Conclusions: The results suggesting that hydrolysate could be added to food oils as an efficient antioxidant. It might be useful for food additives, diet nutrients and pharmaceutical agents.

Keywords: Housefly larvae, Protein hydrolysate, Antioxidant activity, Optimization, Two step enzymatic hydrolysis

\section{Background}

Antioxidants are one of the most important food additives that are widely used in the food industry. Currently, antioxidants are primarily produced by chemical synthesis, and they could accumulate in vivo and cause disease. Therefore, it is important to identify and use natural

\footnotetext{
* Correspondence: Isszwq@mail.sysu.edu.cn

'Equal contributors

'State Key Laboratory of Biocontrol, School of Life Sciences, Sun Yat-sen University, Guangzhou 510275, China

Full list of author information is available at the end of the article
}

antioxidants. It has been shown that there are many antioxidative peptides present in protein hydrolysate that possess a strong capacity to inhibit both peroxidation of micro-biomolecules and free radicals [1-5]. Antioxidative peptides have the potential to be exploited as new natural antioxidants or functional foods. There is a great market potential in the medical and cosmetic fields for antioxidative peptides.

The functional properties of proteins can be improved by enzymatic hydrolysis under controlled conditions [6]. Consequently, enzymatic hydrolysis used for preparation

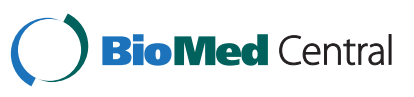

(c) 2013 Wang et al.; licensee BioMed Central Ltd. This is an Open Access article distributed under the terms of the Creative Commons Attribution License (http://creativecommons.org/licenses/by/2.0), which permits unrestricted use, distribution, and reproduction in any medium, provided the original work is properly cited. 
of antioxidative peptides is a new hotspot in the field of natural antioxidants. Reactions occurred under mild conditions with accurate site specific degradation are repeatable and cause little damage to the biological activity of proteins. The substrates for enzymatic hydrolysis are usually plants and aquatic animals [4,7-17]. Some insects are also gaining attention because they are rich in proteins and bioactive peptides [18].

Housefly larvae, edible insects found in some areas of China, can now be easily reared on a large-scale with simple techniques and at low cost; however, they are commonly used for animal feed. In our laboratory, the antimicrobial peptides in housefly larvae have been isolated and identified $[19,20]$. The objectives of the present research are to obtain antioxidant peptides through enzymatic hydrolysis of housefly larvae, to study their amino acid compositions and functional properties, and to ensure a long lasting shelf life of the product.

\section{Results and discussion}

Optimization of enzymatic hydrolysis

Orthogonal experiment was designed to illustrate impact of different hydrolysis factors on DH of housefly larvae. To obtain hydrolysates with high $\mathrm{DH}$ and scavenging radical activity, the optimum hydrolysis condition was determined using the orthogonal experiment, the maximum DH of TSG could be obtained for hydrolysis conditions, it was confirmed the DH of two enzymatic processes were $18.01 \%$ (enzyme-to-substrate ratio, E/S) and $12.60 \%(\mathrm{E} / \mathrm{S})[13]$.

Bioactive peptides usually contain 2-20 amino acid residues per molecule [21]; the lower their molecular weights, the higher their chances of crossing the intestinal barrier and exerting a biological effect [22]. Previous work on antioxidative peptides had shown that peptides with 5-16 amino acid residues can exhibit potent antioxidant activity $[3,23]$. As a result, a two-step hydrolysis reaction was adopted, and orthogonal experiments were designed to optimize processing conditions to obtain smaller peptides, which might possess potent antioxidant activity.

The influence of $\mathrm{pH}(\mathrm{A})$, temperature (B), the solid/liquid ratio ( $C$ of first step), the amount of enzyme ( $D$ of first step, $C$ of second step) and time (E of first step, D of second step) on the hydrolysis by Alcalase ${ }^{\odot}$ and Flavourzyme $^{\mathrm{Tx}}$ were determined using range $(\mathrm{R})$ and ANOVA analyses. Statistical analysis results showed that among the independent variables, temperature, the solid/liquid ratio and the concentration of enzymes had relatively higher significant effects $(\mathrm{p}<0.05)$ on hydrolysis as compared to $\mathrm{pH}$, time and the interactions between factors.

Because there was no significant difference between $\mathrm{pH}$ and time levels, another experiment was conducted to identify the best processing conditions for each step of hydrolysis, as shown in Figure 1. The hydrolysis conditions for obtaining the optimum $\mathrm{DH}$ in the first step were as follows: Alcalase ${ }^{\circ} 2.4 \mathrm{~L}$ at $\mathrm{pH} 8,55^{\circ} \mathrm{C}$, a solid to liquid ratio of $1 / 20,2 \%$ protease, and a reaction time of $5 \mathrm{~h}$. In the second step, using Flavourzyme ${ }^{\mathrm{Ts}}$, the conditions were set to $\mathrm{pH} 7,55^{\circ} \mathrm{C}$, a solid to liquid ratio of $1 /$ 20, $200 \mathrm{U} / \mathrm{g}$ protease (based on the protein of substrate), and a reaction time of $8 \mathrm{~h}$.

\section{Molecular weight distribution of hydrolysate}

The electrophoretic pattern of the fractionated hydrolysate presented in Figure 2 indicated that the peptides formed due to hydrolysis were less than $16 \mathrm{kDa}$ in molecular weights, corroborating well with the higher $\mathrm{DH}$ values observed in the study.

For the housefly larvae protein hydrolysate to be of high nutritional value, the dietary protein should be rich in low molecular weight peptides with the lowest possible amounts of free amino acids [24]. Hence, the protein hydrolysate prepared from the housefly larvae can be considered of high nutritional value.

\section{Antioxidant activity \\ Radical scavenging activity}

Antioxidants activity depends on many different factors. We used three methods to characterize antioxidant activity based on the radical scavenging capacity: DPPH (1, 1-diphenyl-2- picrylhydrazyl) radical, the superoxide radical, and hydroxyl radical inhibition.

It is well known that the majority of free radicals are high biological activities while they exist only in short time, but DPPH can keep stable at room temperature. The DPPH free radicals are stable in ethanol and show maximum absorbance at $517 \mathrm{~nm}$. DPPH radicals can interact with antioxidant, as a results, the radicals are scavenged and the absorbance is decreased. So, the $\mathrm{DPPH}$ radicals can be used to measure the scavenging activity of antioxidant compounds [25].

Superoxide radical, which is usually formed in cellular oxidation reactions, has a strong oxidation activity, it can produce singlet oxygen, hydroxyl radical, hydrogen peroxide and other strong oxidizing substances, it is very important in the initial reaction and the chain reaction of lipid oxidation [2]. Superoxide anion radical can cause damage to DNA and membrane of cell. So, it is very important to scavenge superoxide anion radical [2].

It is generally considered that the radical system could be used to evaluation antioxidant activity via radicalscavenging capacities of a antioxidant [26]. Hydroxyl radicals are the most reactive and can react with almost all the biomolecules in the cell, as a result induce damage to cells [27]. 


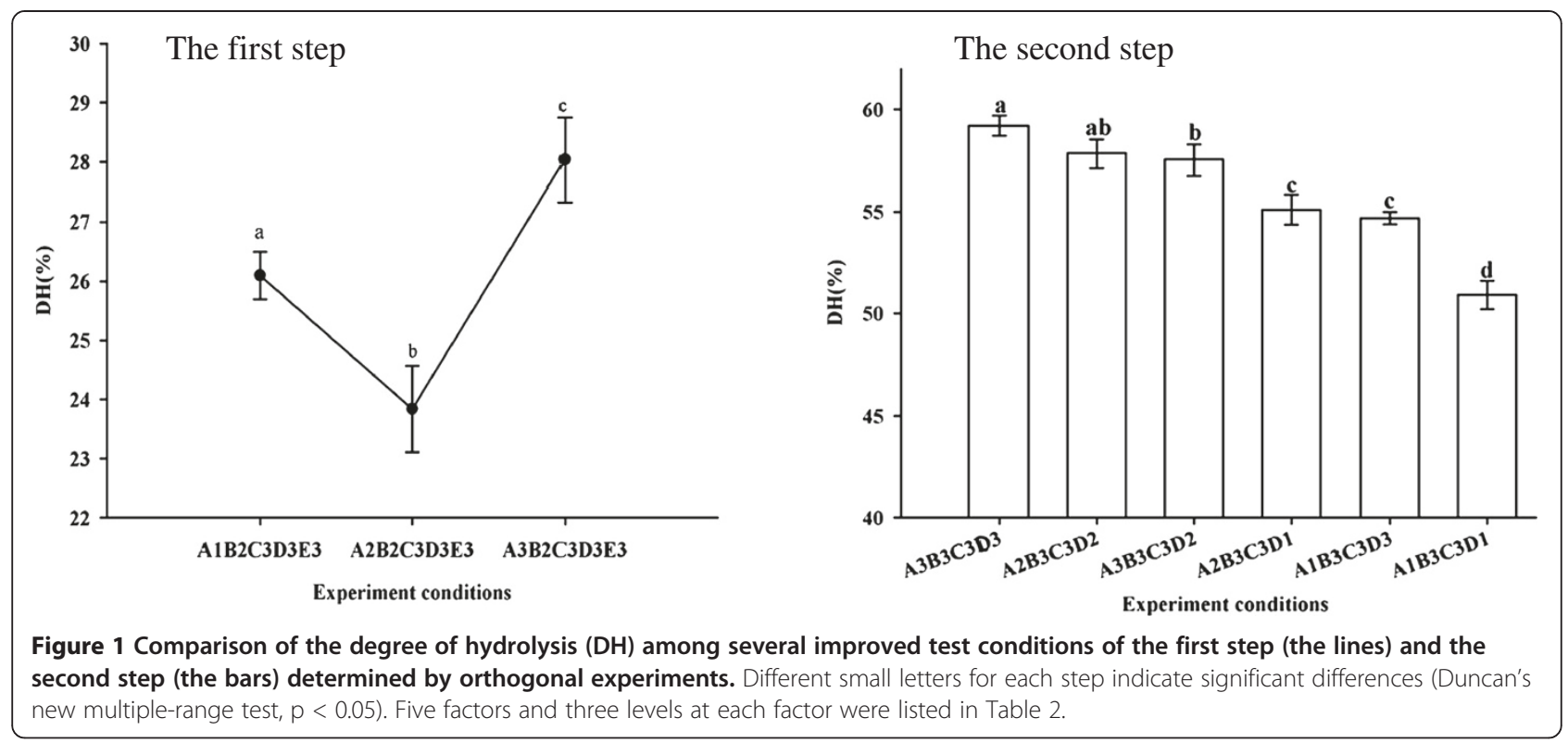

Statistical analysis results showed that among the independent variables, The superoxide radical, DPPH radical, and hydroxyl radical scavenging abilities of hydrolysate had relatively higher significant effects $(\mathrm{p}<0.05)$ on hydrolysis as compared to Vc or TBHQ.

The superoxide radical, DPPH radical, and hydroxyl radical inhibition of the fractionated hydrolysate of housefly larvae proteins were shown to be dose-dependent: the higher the hydrolysate concentration, the higher the superoxide radical, DPPH and hydroxyl radical scavenging capacity for the hydrolysate (Figure 3). The superoxide radical, DPPH radical, and hydroxyl radical scavenging abilities of hydrolysate at $10 \mathrm{mg} / \mathrm{mL}, 20 \mathrm{mg} / \mathrm{mL}$ and

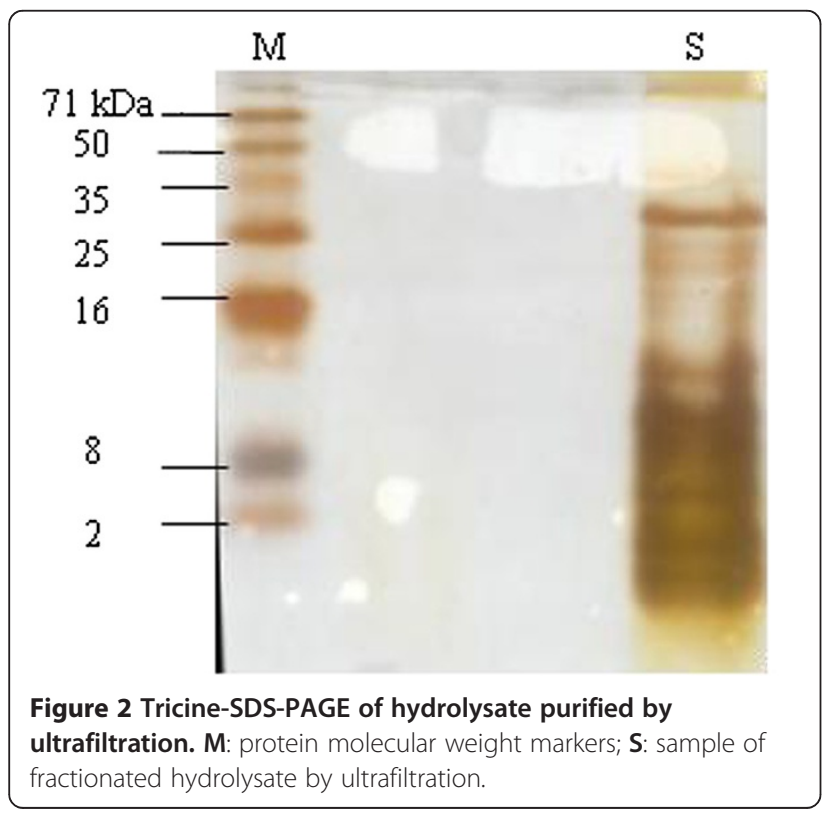

$50 \mathrm{mg} / \mathrm{mL}$ were similar to those of $\mathrm{Vc}$ at $1 \mathrm{mg} / \mathrm{mL}$ (Figure 3A), $0.05 \mathrm{mg} / \mathrm{mL}$ (Figure 3B) and $0.25 \mathrm{mg} / \mathrm{mL}$ (Figure 3C), respectively. The radical inhibition of hydrolysate was considerably lower than that of Vc or TBHQ at tested concentrations.

The $\mathrm{IC}_{50}$ value is applied as an indicator to evaluate the scavenging activity. The lower the $\mathrm{IC}_{50}$ value, the higher the free radical scavenging ability. The $\mathrm{IC}_{50}$ values for the scavenging ability of the hydrolysate for superoxide radicals, DPPH radicals and hydroxyl radicals were approximately $25 \mathrm{mg} / \mathrm{mL}, 2.5 \mathrm{mg} / \mathrm{mL}$ and $1 \mathrm{mg} / \mathrm{mL}$, respectively (Figure 3 ).

In the present study, the hydrolysate did not exhibit substantial ion chelation.

Among all tested $\mathrm{DH}$ values, the higher the $\mathrm{DH}$, the higher the DPPH radical scavenging capacity for the hydrolysate at $40 \mathrm{mg} / \mathrm{mL}$ (Figure 3D), indicating that, high $\mathrm{DH}$ may produce more antioxidant peptides. This $\mathrm{DH}-$ dependence of DPPH radical scavenging ability was found to be different from buckwheat [7], but the same as porcine collagen hydrolysate [28]. Some previous studies indicated that high DPPH or other radical scavenging activities for the protein hydrolysate or peptides are usually associated with highly hydrophobic amino acids or hydrophobicity $[1,29]$, our results are consistent with those data (Table 1, Figure 4). The higher the concentration and the higher level of the DPPH radical scavenging activity were found in our experiment, similar to those results reported previously [30,31]. An isolated $1 \mathrm{kDa}$ peptide from a peptic hydrolysate of casein showed superoxide anion as well as DPPH radical scavenging activity [32]. The scavenging activity against superoxide radical for wheat germ protein hydrolysates $(0-0.60 \mathrm{~g} / \mathrm{L})$ ranges from $0 \%$ to $75.40 \%$ [31]. The 

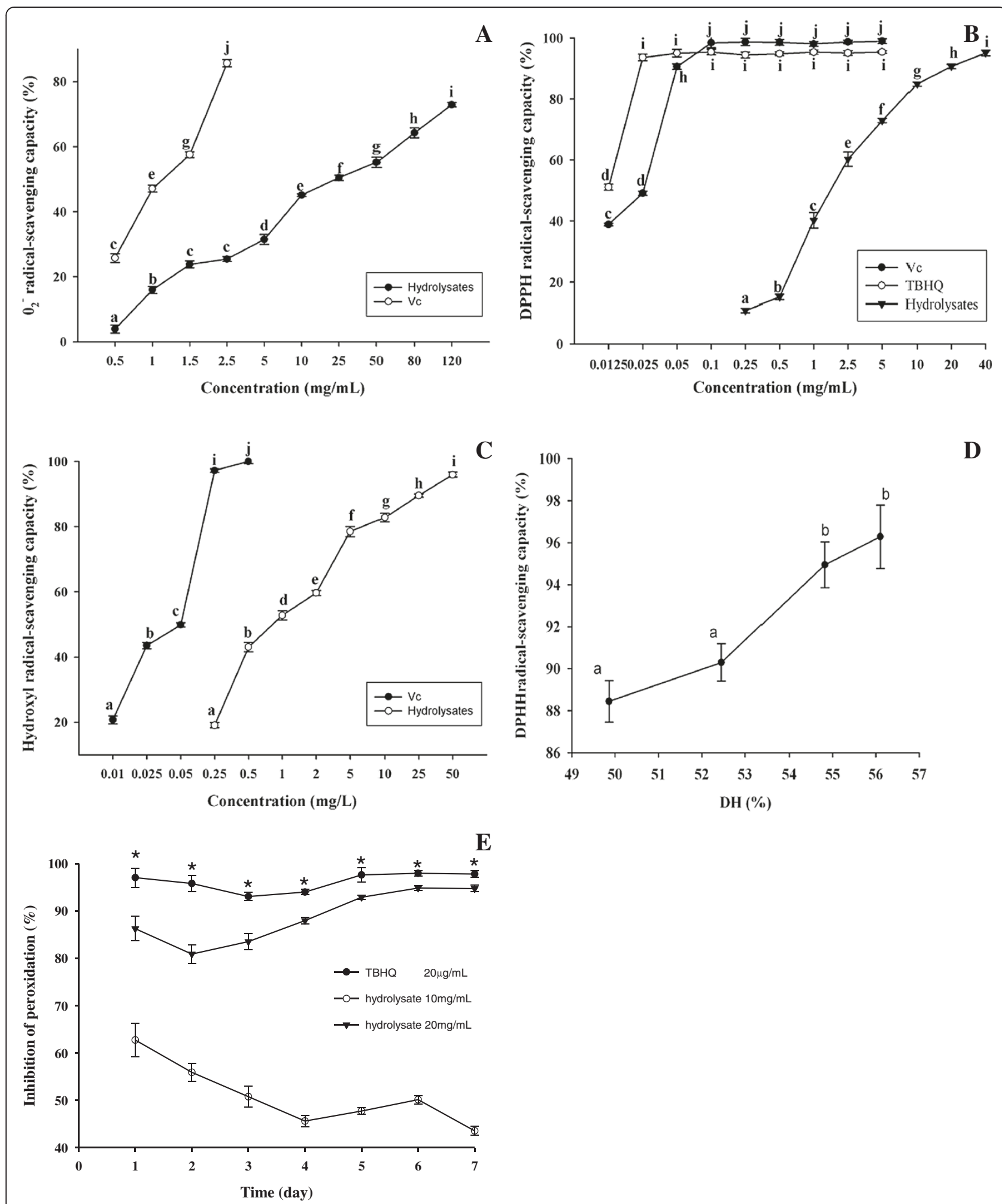

Figure 3 Antioxidant activity of fractionated hydrolysate. A. Superoxide radical scavenging activity of purified hydrolysates; B. DPPH radical scavenging activity of purified hydrolysates; $\mathbf{C}$. Hydroxyl radical scavenging activity of purified hydrolysates. $\mathbf{D}$. Effects of DH on the antioxidative activity of purified hydrolysates at $40 \mathrm{mg} / \mathrm{mL}$. E. Effect of purified hydrolysates on the inhibition of linoleic acid peroxidation. Different letters within the same fold line indicate significant differences (Duncan's new multiple-range test, $p<0.05$ ). 
Table 1 Amino acid compositions of fractionated hydrolysate and comparison with the FAO/WHO reference of essential amino acids requirements ( $\mathrm{mg}$ per $\mathrm{g}$ of protein)

\begin{tabular}{|c|c|c|c|c|c|c|}
\hline \multirow[t]{2}{*}{ Amino acids } & \multicolumn{2}{|c|}{ Content of amino acids } & \multicolumn{4}{|c|}{ Reference protein ${ }^{d}$} \\
\hline & Hydrolysate & Larvae & 1 year old infant & 2-5 years old child & $10-12$ years old child & Adult \\
\hline Isoleucine* & 52 & 34 & 46 & 28 & 28 & 13 \\
\hline Leucine* & 78 & 55 & 93 & 66 & 44 & 19 \\
\hline Lysine* & 51 & 68 & 66 & 58 & 44 & 16 \\
\hline Cystine & 3 & 5 & $42^{b}$ & $25^{\mathrm{b}}$ & $22^{\mathrm{b}}$ & $17^{\mathrm{b}}$ \\
\hline Methionine ${ }^{*}$ & 32 & 32 & & & & \\
\hline Threonine* & 54 & 38 & 43 & 34 & 28 & 9 \\
\hline Tryptophan*a & - & - & 17 & 11 & 9 & 5 \\
\hline Valine ${ }^{*}$ & 74 & 61 & 55 & 35 & 25 & 13 \\
\hline Phenylalanine* & 80 & 67 & - & - & $22^{c}$ & $19^{c}$ \\
\hline Tyrosine & 43 & 70 & - & - & & \\
\hline Histidine & 9 & 24 & & & & \\
\hline Aspartic acid & 117 & 89 & - & - & - & - \\
\hline Serine & 49 & 34 & - & - & - & - \\
\hline Glutamic acid & 160 & 133 & - & - & - & - \\
\hline Glycine & 47 & 39 & - & - & - & - \\
\hline Alanine & 77 & 50 & - & - & - & - \\
\hline Arginine & 16 & 41 & - & - & - & - \\
\hline Proline & 37 & 36 & - & - & - & - \\
\hline Total amino acids & $978^{a}$ & $877^{a}$ & & & & \\
\hline Essential amino acids / \% & $43^{\mathrm{a}}$ & $41^{\mathrm{a}}$ & & & & \\
\hline
\end{tabular}

* Essential amino acids; ${ }^{a}$ Tryptophan was not determined and counted due to degradation; ${ }^{\mathrm{b}}$ Sum of Cystine and Methionine; ${ }^{\mathrm{c}}$ Sum of Phenylalanine and Tyrosine; ${ }^{d}$ Essential amino acids of reference protein according to FAO/WHO cited by Tang et al [33].

scavenging activity against superoxide radical of the protein hydrolysate was lower than wheat germ protein hydrolysates, indicating effective chain breaking antioxidant of the protein hydrolysate.

Antioxidative activity of protein hydrolysates also depends on the proteases and hydrolysis conditions employed [34].

\section{Inhibition of linoleic acid peroxidation}

Since lipid peroxidation is thought to proceed via radical mediated abstracted of hydrogen atoms from methylene carbons in polyunsaturated fatty acids [26], The inhibition of linoleic acid peroxidation by fractionated hydrolysate was measured as shown in Figure 3E. In the present experiment, the autoxidation of linoleic acid was inhibited to varying extents by different concentrations of hydrolysate $(10 \mathrm{mg} / \mathrm{mL}, 20 \mathrm{mg} / \mathrm{mL})$. The inhibition activity of hydrolysate at $20 \mathrm{mg} / \mathrm{mL}$ was similar to that of TBHQ $(0.02 \mathrm{mg} / \mathrm{mL})$, which was distinctly better than at $10 \mathrm{mg} / \mathrm{mL}$. The underlying mechanism for the significantly different effect on inhibition in regards to concentration is still not clear, but it may be partially related to radical chain reactions.
Free radicals with a majority of reactive oxygen species (ROS) are usually unstable and react readily with other groups or substances in the body, resulting in cell damage and human disease [35]. Therefore, quenching of free radicals and ROS is probably one of the most effective defenses of a living body against various diseases.

\section{Amino acid composition of hydrolysate}

Amino acid composition of the lyophilized fractionated hydrolysate was analyzed in order to determine the possible effect of the amino acid profile on antioxidant biological activity. Its amino acid composition is presented in Table 1. The total amount of amino acid is $978 \mathrm{mg}$ per $1000 \mathrm{mg}$ of sample. Some amino acids show antioxidant activity, such as Met, His, Cys and Tyr, His shows strong radical scavenging biological activity because its imidazole ring was decomposed [30,36]. Therefore, the antioxidant activities of the lyophilized hydrolysates seemed to be caused by these amino acids in the peptides. Moreover, the antioxidant activity of the lyophilized hydrolysates depended upon the amino acid sequence of the peptides. The analysis of the amino acid composition of fractionated hydrolysate showed that the 

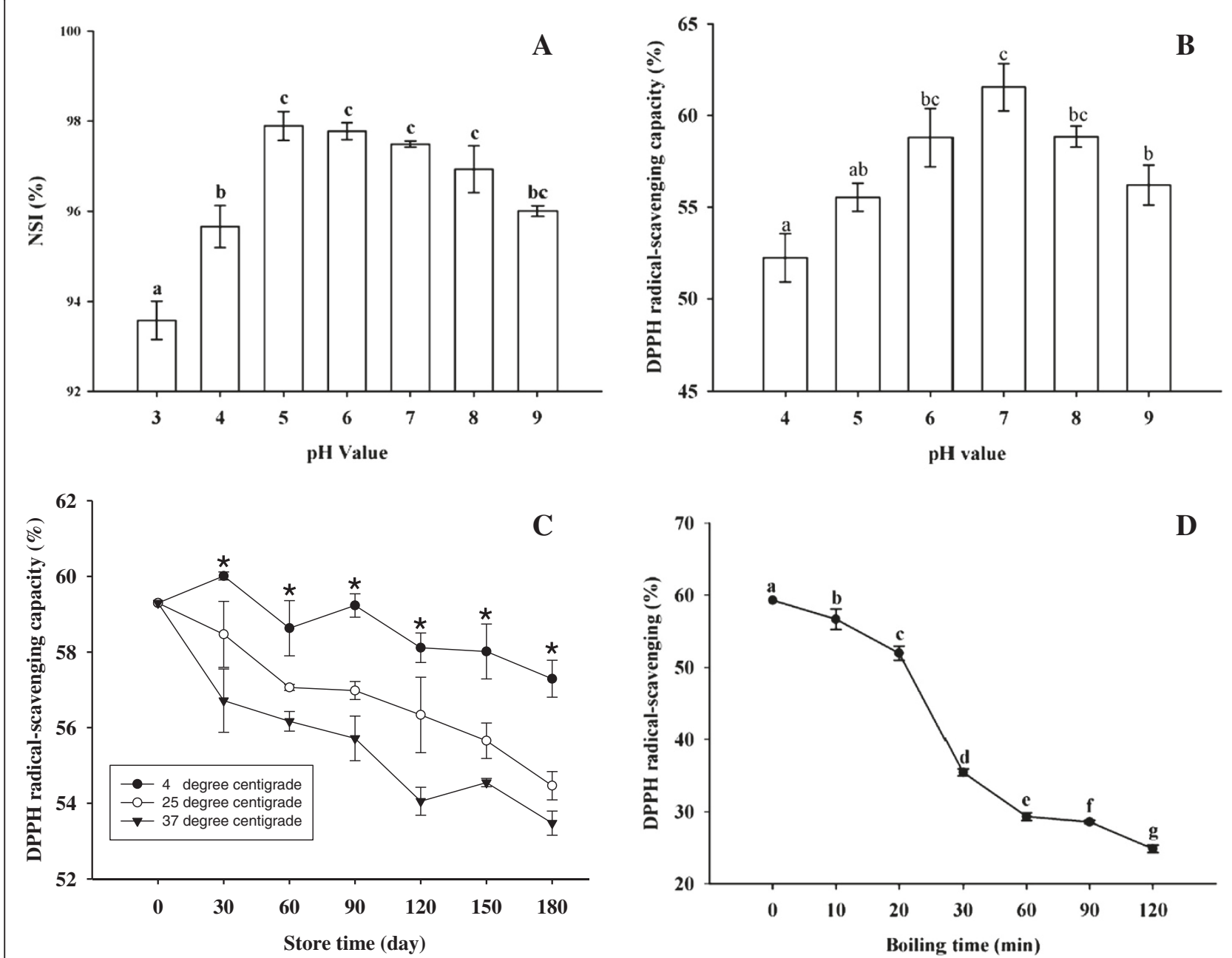

Figure 4 Solubility and stability of the housefly larvae hydrolysate. A. Effects of $\mathrm{pH}$ on the solubility of purified hydrolysates; $\mathbf{B}$. Effects of $\mathrm{pH}$ on the antioxidative activity of purified hydrolyates. $\mathbf{C}$. Effects of temperature on the antioxidative activity of purified hydrolysates; $\mathbf{D}$. Effects of boiling time on the antioxidative activity of purified hydrolysates. Different letters within the same fold line indicate significant differences (Duncan's new multiple-range test, $p<0.05$ ).

content of essential amino acids accounted for $43 \%$ of total amino acids, and the equilibrium level fulfilled the suggested pattern of requirements by Food and Agriculture Organization/World Health Organization for children and adults.

The nutritional value of any ingredient depends on a protein's capacity to fulfill the needs of the organism with respect to its essential amino acids.

\section{Functional properties of protein hydrolysate}

Lyophilized hydrolysates were almost 100\% soluble over a wide range of $\mathrm{pH}$ values (3-9) (Figure 4). Hydrolysate is known to have excellent solubility at a high $\mathrm{DH}$ $[37,38]$. Hydrolysis potentially influenced the molecular structure, hydrophobicity and polar groups of the hydrolysate $[39,40]$. Higher DH meant smaller peptides, which were expected to have proportionally more polar residues and the ability to form hydrogen bonds with water, thereby improving the solubility [38]. The Housefly larvae protein hydrolysates had a $\mathrm{DH}$ of approximately $60 \%$ (Figure 1), and fractionated hydrolysates consisted of low molecular weight peptides (Figure 2) that were mostly in the range of $2 \mathrm{kDa}-8 \mathrm{kDa}$, which may support the findings of high solubility.

The high solubility of the housefly larvae protein hydrolysate over a wide range of $\mathrm{pH}$ indicated a substantially useful characteristic for additive applications. The characteristics of hydrolysate have been found to directly affect functional properties and uses as food ingredients [40].

Lyophilized hydrolysate was almost entirely active at $\mathrm{pH}$ 5 -pH 8 between $0^{\circ} \mathrm{C}-4^{\circ} \mathrm{C}$ and at room temperature during the first 6 months of storage. After boiling for $30 \mathrm{~min}$, the activity was significantly decreased (Figure 4). 


\section{Conclusions}

The two-step hydrolysis of the housefly larvae using Alcalase $^{\oplus}$ followed by Flavourzyme ${ }^{\mathrm{Tw}}$ resulted in a degree of hydrolysis of approximately $60 \%$ under optimized conditions. A mixture of small peptides $(2 \mathrm{kDa}-8 \mathrm{kDa})$ was obtained after decoloration using activated clay and fractionation with ultrafiltration consecutively using $50 \mathrm{kDa}$ and $10 \mathrm{kDa}$ devices. The hydrolysates at $25 \mathrm{mg} /$ $\mathrm{mL}, 2.5 \mathrm{mg} / \mathrm{mL}$ and $1 \mathrm{mg} / \mathrm{mL}$ exhibited $50 \%, 60 \%$ and $50 \%$ of scavenging activity on superoxide radicals, DPPH radicals and hydroxyl radicals, respectively. The inhibition of linoleic peroxidation by purified hydrolysate at $20 \mathrm{mg} / \mathrm{mL}$ was close to $20 \mu \mathrm{g} / \mathrm{mL}$ TBHQ, suggesting that hydrolysate could be added to food oils as an efficient antioxidant. In addition, hydrolysate is very nutritious and can be easily stored. In conclusion, hydrolysates might be useful for food additives, diet nutrients and pharmaceutical agents.

\section{Methods \\ Materials}

Housefly larvae were reared in our laboratory at $28^{\circ} \mathrm{C} \pm 1^{\circ} \mathrm{C}$, RH 60\%-80\%. The proteases employed for the optimization studies were Alcalase $2.4 \mathrm{~L}(2.4 \mathrm{AU} / \mathrm{g})$ and Flavourzyme ${ }^{\mathrm{Tx}}$ (1000 LAPU/g). Both proteases were purchased from Novozymes A/S (Gladsaxe, Denmark). Linoleic acid, 1,1-Diphenyl-2-picrylhydrazyl (DPPH), ferrozine and Vitamin $C(\mathrm{Vc})$ were purchased from Sigma-Aldrich (Sigma-Aldrich Inc., St. Louis, MO, USA). Tertiary butylhydroquin-one (TBHQ) was purchased from TaiBang Co., Ltd (Guangzhou, China). Other chemicals and reagents used were of analytical grade and commercially available.

\section{Optimization of enzymatic hydrolysis}

Orthogonal experiments were designed to optimize hydrolysis conditions and to obtain the highest amount of small peptides. Five factors $(\mathrm{pH}$, temperature, time, solid/liquid ratio, and amount of protease) were varied at three levels for each factor, as shown in Table 2. The larvae were first hydrolyzed with endopeptidase Alcalase 2.4 L, followed by a mixture of endo- and exopeptidase
(Flavourzyme $^{\mathrm{Tm}}$ ) to enhance hydrolysis and improve flavor. The orthogonal table, $\mathrm{L}_{27}\left(3^{13}\right)$, was used in both steps of the experiment. Degree of hydrolysis (DH) was measured for each test run and used as the index for optimizing the hydrolysis conditions.

\section{Production and isolation of protein hydrolysate}

Third instars' maggots were dried at $80^{\circ} \mathrm{C}$ after washed, then the bound water was removed at $105^{\circ} \mathrm{C}, 12 \mathrm{~h}-24 \mathrm{~h}$, the dried housefly larvae $(1 \mathrm{~g})$ were ground into a coarse powder and suspended in distilled water at a given volume. The hydrolysis reaction was initiated by the addition of 2.4 L Alcalase ${ }^{\bullet}$ under the given conditions and was stopped by heating at $100^{\circ} \mathrm{C}$ for $5 \mathrm{~min}$ to deactivate the enzymes. The $\mathrm{pH}$ of the mixture was maintained constant during the hydrolysis by addition of $1 \mathrm{~mol} / \mathrm{L} \mathrm{NaOH}$. After centrifugation at $10,000 \mathrm{~g}$ for $20 \mathrm{~min}$, the supernatant was collected.

$\mathrm{DH}$ is the percentage ratio between the number of peptide bonds cleaved and the total number of peptide bonds in the substrate studied. DH was calculated as follows:

$$
\begin{aligned}
& D H(\%)=[\text { content of } \alpha \text {-amino nitrogen }(g) / \\
& \text { content of total analyzable Kjeldahl nitrogen }(g)] \times 100 \%
\end{aligned}
$$

The content of $\alpha$-amino nitrogen was determined according to United States Pharmacopeia [41], and the content of total analyzable Kjeldahl nitrogen was determined by a Kjeltec Auto 1030 Analyzer (Tecator AB, Sollentuna, Sweden) [42].

The supernatant was decolored by activated clay $(8 \%$, room temperature, $2 \mathrm{~h}$ ) and was then filtered using a $0.22 \mu \mathrm{M}$ filter membrane (Millipore, Massachusetts, U.S.A). To obtain low molecular weight peptides, the decolored hydrolysate was ultrafiltered with $50 \mathrm{kDa}$, followed by $10 \mathrm{kDa}$ ultrafiltration devices (Millipore, Massachusetts, U.S.A). The fraction of proteins with lower molecular weights was collected, lyophilized to dryness in a vacuum, and used for the following experiments. The lyophilized powder was stored at $-40^{\circ} \mathrm{C}$ before use.

\begin{tabular}{|c|c|c|c|c|c|c|}
\hline \multirow[t]{2}{*}{ Factor } & \multicolumn{3}{|l|}{ First step } & \multicolumn{3}{|c|}{ Second step } \\
\hline & 1 & 2 & 3 & 1 & 2 & 3 \\
\hline $\mathrm{pH}(\mathrm{A})$ & 6.0 & 7.0 & 8.0 & 5.0 & 6.0 & 7.0 \\
\hline Temperature (B) & $50.0^{\circ} \mathrm{C}$ & $55.0^{\circ} \mathrm{C}$ & $60.0^{\circ} \mathrm{C}$ & $45.0^{\circ} \mathrm{C}$ & $50.0^{\circ} \mathrm{C}$ & $55.0^{\circ} \mathrm{C}$ \\
\hline Solid/liquid ratio ( $\left.w / v, C^{a}\right)$ & $1 / 5$ & $1 / 10$ & $1 / 20$ & - & - & - \\
\hline (enzyme-to-substrate ratio, $E / S, D^{a}, C^{b}$ ) ${ }^{*}$ & $0.012 \mathrm{AU} / \mathrm{g}$ & $0.024 \mathrm{AU} / \mathrm{g}$ & $0.048 \mathrm{AU} / \mathrm{g}$ & $50 \mathrm{LAPU} / \mathrm{g}$ & $100 \mathrm{LAPU} / \mathrm{g}$ & $200 \mathrm{LAPU} / \mathrm{g}$ \\
\hline Time $\left(E^{a}, D^{b}\right)$ & $1.0 \mathrm{~h}$ & $2.5 \mathrm{~h}$ & $5.0 \mathrm{~h}$ & $4.0 \mathrm{~h}$ & $6.0 \mathrm{~h}$ & $8.0 \mathrm{~h}$ \\
\hline
\end{tabular}

Table 2 Factors and levels for orthogonal experiment design

${ }^{a}$ Factors for the first step of hydrolysis; ${ }^{b}$ Factors for the second step of hydrolysis.

${ }^{*}$ The protease is Alcalase ${ }^{\ominus} 2.4 \mathrm{~L}$ at the first step, and Flavourzyme ${ }^{\mathrm{Tm}}$ at the second step. 


\section{Molecular weight distribution of hydrolysate}

The housefly larvae hydrolysates were analyzed by Tricine-SDS-PAGE according to [43] with slight modifications; $16.5 \%$ separating gel, $10 \%$ spacer gel and $4 \%$ stacking gel. The lyophilized hydrolysate was dissolved (20 $\mathrm{mg} / \mathrm{mL})$ in loading buffer (12\% SDS, 6\% $\beta$ mercaptoethanol, 30\% glycerol, $0.05 \%$ Coomassie blue G-250, and $150 \mathrm{mmol} / \mathrm{L}$ Tris- $\mathrm{HCl}$ at $\mathrm{pH} 7.0$ ), heated at $100^{\circ} \mathrm{C}$ for $5 \mathrm{~min}$, and centrifuged at $12,000 \mathrm{~g}$ for $2 \mathrm{~min}$.

The electrophoresis was performed in a mini electrophoresis apparatus (Bio-Rad, California, USA) at room temperature using the following procedure. The voltage was kept constant at $30 \mathrm{~V}$ until the samples completely left the stacking gel, then the voltage was kept constant at $90 \mathrm{~V}-100 \mathrm{~V}$ until the tracking dye was close to the bottom of the gel. The loading volume of the samples and the standards was $5 \mu \mathrm{L}-10 \mu \mathrm{L}$. The protein bands were stained using silver nitrate according to the staining method used by [44]. The approximate molecular weights of the hydrolysate were determined using appropriate prestained protein molecular weight marker 2 kDa-71 kDa (SBS Genetech Co., Ltd, Beijing, China).

\section{Determination of antioxidant activity}

\section{1, 1-Diphenyl-2-picrylhydrazyl (DPPH) radical scavenging activity}

A method published by [45] was modified and used to test for $\mathrm{DPPH}$ radical scavenging activity. Briefly, $0.5 \mathrm{~mL}$ of $0.05 \mathrm{mg} / \mathrm{ml}$ the sample solution was mixed with $0.5 \mathrm{~mL}$ of freshly prepared $50 \mu \mathrm{mol} / \mathrm{L} \mathrm{DPPH}$ in an ethanol solution. The resulting solution was then incubated at room temperature for $50 \mathrm{~min}$ in the dark prior to spectrophotometric analysis at $517 \mathrm{~nm}$ using a UV-spectrophotometer (Bio-Rad, California, U.S.A). A lower absorbance value at $517 \mathrm{~nm}$ indicated a higher DPPH scavenging activity. The capability to scavenge the DPPH radicals was calculated according to the following equation:

$$
\begin{aligned}
& \text { DPPHradical - scavenging activity }(\%) \\
& \quad=\left[1-\left(\mathrm{A}_{\mathrm{S}}-\mathrm{A}_{0}\right) / \mathrm{A}_{\text {control }}\right] \times 100 \%
\end{aligned}
$$

Variables $A_{s}, A_{0}$, and $A_{\text {control }}$ represent the absorbance of the test sample, the blank sample without DPPH solution, and the DPPH solution without the test sample, respectively.

\section{Ferrous ion-chelating ability}

The $\mathrm{Fe}^{2+}$ chelating ability of the hydrolysate was determined according to the method reported by [46], with modifications. A test sample $(250 \mu \mathrm{L}$ of various concentrations) in phosphate buffer solution ( $\mathrm{pH} 7.4,925 \mu \mathrm{L})$ was treated with $\mathrm{FeCl}_{2}(2 \mathrm{mmol} / \mathrm{L}, 25 \mu \mathrm{L})$ and ferrozine $(5 \mathrm{mmol} / \mathrm{L}, 50 \mu \mathrm{L}$ ) for $10 \mathrm{~min}$ at room temperature in the dark. The absorbance of the resulting solution was measured at $562 \mathrm{~nm}$. A lower absorbance of the reaction mixture indicated a higher $\mathrm{Fe}^{2+}$ chelating ability. The chelating ability of the ferrous ions was calculated using the following equation:

Variables $A_{s}, A_{0}$, and $A_{\text {control }}$ represent the absorbance of the test sample, the blank sample in which ferrozine was replaced by distilled water, and a control in which the sample was replaced by distilled water, respectively.

\section{Antioxidant activity in the linoleic acid emulsion system}

The thiocyanate method [47] was adopted to determine the antioxidant activity of the housefly larvae hydrolysate in a linoleic acid emulsion system as described by [48] Each sample was diluted in $0.5 \mathrm{~mL}$ of absolute ethanol and mixed with the linoleic acid emulsion $(2.5 \mathrm{~mL}, 0.02$ $\mathrm{mol} / \mathrm{L}, \mathrm{pH} 7.0)$ in phosphate buffer $(2 \mathrm{~mL}, 0.2 \mathrm{~mol} / \mathrm{L}$, $\mathrm{pH}$ 7.0). The linoleic acid emulsion was prepared by mixing and homogenizing $0.2804 \mathrm{~g}$ of linoleic acid, $0.2804 \mathrm{~g}$ of Tween-40 as an emulsifier, and $50 \mathrm{~mL}$ of phosphate buffer. The reaction mixture was incubated at $40^{\circ} \mathrm{C}$ in the dark. Aliquots of $0.1 \mathrm{~mL}$ were taken at several intervals during incubation. The degree of oxidation was measured according to the thiocyanate method by sequentially adding ethanol (4.7 mL, 75\%), ammonium thiocyanate $(0.1 \mathrm{~mL}, 30 \%)$, sample solution $(0.1 \mathrm{~mL})$, and ferrous chloride $(0.1 \mathrm{~mL}, 0.02 \mathrm{~mol} / \mathrm{L}$ in $3.5 \% \mathrm{HCl})$. After the mixture had rested for $3 \mathrm{~min}$, the peroxide value was determined by monitoring the absorbance at $500 \mathrm{~nm}$. A control experiment was performed with linoleic acid excluding the samples. The degree of oxidation was measured every $24 \mathrm{~h}$ until the absorbance of the control was constant. The lipid peroxidation inhibition was calculated using the following equation:

\section{Hydroxyl radical scavenging activity}

The hydroxyl radical scavenging activity of hydrolysate was determined according to the salicylic acid method [49] with some modifications. A solution containing salicylic acid in ethanol ( $9 \mathrm{mmol} / \mathrm{L}, 0.5 \mathrm{~mL})$, an $\mathrm{FeSO}_{4}$ solution $(9 \mathrm{mmol} / \mathrm{L}, 0.5 \mathrm{~mL})$ and $\mathrm{a}_{2} \mathrm{O}_{2}$ solution $(9.8$ $\mathrm{mmol} / \mathrm{L}, 0.5 \mathrm{~mL}$ ) were sequentially added to $0.5 \mathrm{~mL}$ of an appropriately diluted sample. The mixture was measured at $510 \mathrm{~nm}$ after reacting for $30 \mathrm{~min}$ in the dark. The hydroxyl radical scavenging ratio was calculated using the following formula:

Variables $A_{s}, A_{0}$, and $A_{\text {control }}$ represent the absorbance of the test sample, the blank sample in which $\mathrm{H}_{2} \mathrm{O}_{2}$ was replaced by distilled water, and the control in which the sample was replaced by distilled water, respectively.

\section{Superoxide anion scavenging activity}

The pyrogallol autoxidation method was adopted according to [50] to test superoxide anion scavenging activity of the hydrolysate. 


\section{Amino acid composition of hydrolysate}

The analysis of the amino acid composition was performed according to [51]. The samples (30 mg) were hydrolyzed with $10 \mathrm{~mL}$ of $6 \mathrm{~mol} / \mathrm{L} \mathrm{HCl}$. The solutions were sealed in tubes under nitrogen and incubated in an oven at $110^{\circ} \mathrm{C}$ for $22 \mathrm{~h}$. then the hydrolysate was filtrated with filter paper, $1 \mathrm{~mL}$ filtrate was dried under vacuum conditions, after adding $1 \mathrm{~mL}$ deionized water to dried power and drying again, repeat this step, and the resulting dried material was reconstituted with a lithium citrate buffer at $\mathrm{pH}$ 2.2. The amino acids were quantified using a Hitachi L-8800 amino acid analyzer (Hitachi, Tokyo, Japan). Norleucine (Sigma-Aldrich, Inc., St. Louis, Mo., USA) was used as the internal standard. Hitachi 855-350 chromatographic column (Tokyo, Japan) was used in this experiment, temperature of column is $57^{\circ} \mathrm{C}$, the temperature of the reaction column is $134^{\circ} \mathrm{C}, 20 \mu \mathrm{L}$ sample was loaded into chromatographic column. Amino acid composition was reported as g amino acid per 1,000 $\mathrm{g}$ protein. Determinations were performed in triplicate and data correspond to mean values. Standard deviations were in all cases lower than $6 \%$.

\section{Functional properties of protein hydrolysate Solubility}

To determine protein solubility, $250 \mathrm{mg}$ of protein hydrolysate was dispersed in $5 \mathrm{~mL}$ of deionized water, and the $\mathrm{pH}$ of the mixture was adjusted to $3,4,5,6,7,8$, and 9 with $1 \mathrm{~mol} / \mathrm{L} \mathrm{HCl}$ or $1 \mathrm{~mol} / \mathrm{L} \mathrm{NaOH}$. The mixture was stirred at room temperature for $2 \mathrm{~h}$ and centrifuged at $2000 \mathrm{~g}$ for $10 \mathrm{~min}$. The Kjeldahl nitrogen in the supernatant and total Kjeldahl nitrogen of hydrolysate was determined by a Kjeltec Auto 1030 Analyzer (Tecator AB, Sollentuna, Sweden). Protein solubility was calculated as follows:

\section{Stability of antioxidant activity}

The antioxidant activity stability was studied using $\mathrm{DPPH}$, the radical-scavenging method given by [45] with various $\mathrm{pH}$ and temperatures. To determine the stability in different $\mathrm{pH}$ environments, the lyophilized hydrolysate was dispersed in distilled water $(2.5 \mathrm{mg} / \mathrm{L})$ and the $\mathrm{pH}$ was adjusted to $4,5,6,7,8$, and 9 with $1 \mathrm{~mol} / \mathrm{L} \mathrm{HCl}$ or $1 \mathrm{~mol} / \mathrm{L} \mathrm{NaOH}$ before adding protein $(2.5 \mathrm{mg})$.

To determine the stability at different storage temperatures, lyophilized hydrolysate was stored at $0^{\circ} \mathrm{C}, 4^{\circ} \mathrm{C}$, $25^{\circ} \mathrm{C}$, and $37^{\circ} \mathrm{C}$, with $60 \%-75 \%$ moisture. The DPPH radical scavenging activity was measured every 30 days for 180 days.

The hydrolysate $(2.5 \mathrm{mg} / \mathrm{mL})$ was boiled at $100^{\circ} \mathrm{C}$ for $10 \mathrm{~min}, 20 \mathrm{~min}, 30 \mathrm{~min}, 60 \mathrm{~min}, 90 \mathrm{~min}$ or $120 \mathrm{~min}$. After cooling to room temperature, the DPPH radical scavenging activity was measured.

\section{Statistical analysis}

In this study, each experiment was conducted in triplicate, and the values were expressed as mean \pm Se, except that both orthogonal experiments were conducted once. The $\mathrm{SAS}^{\oplus}$ system version 9.1 (SAS Institute Inc., Cary, NC, USA) was used for data processing. Analysis of variance (ANOVA) was performed. Differences in mean values were determined using Duncan's new multiplerange test. Values of $\mathrm{p}<0.05$ were considered to be statistically significant.

\begin{abstract}
Abbreviations
AU: Anson unit; RH: Relative humidity; AP: Ammonium persulfate; D: Day; Da: Dalton; $\mathrm{ddH}_{2} \mathrm{O}$ : Double distilled water; $\mathrm{DH}$ : Degree of hydolysis; DPPH: 1,1-Diphenyl-2-picrylhydrazyl; G: Gram; g(rcf): Gravity(relative centrifugal force); kDa: Kilodalton; hr: Hour; M: Molarity(mol/L); min: Minute; N: Normality(g/L); OD: Optical density; Rpm: Revolution per minute; S: Second; SDS: Sodium dodecyl sulfate; SDS-PAGE: SDS-polyacrylamide gel electrophoresis; TEMED: N,N,N',N'-Tetramethylene-Diamine; Tricine: N-(Tri (hydroxymethyl)) glycine; Tris: Tri(hydroxymethyl)-aminomethanetions.
\end{abstract}

\section{Competing interests}

The authors declare that they have no competing interests.

\section{Authors' contributions}

JW designed the experiments, analyzed the data, drafted the paper, carried out the Optimization, Production and isolation, Determination, Amino acid composition, electrophoresis and functional experiments. YW contributed to the isolation, functional, Amino acid composition experiments and manuscript editing. XD and XZ contributed to Production and isolation experiments. WZ initiated the project, designed the experiments, revised the paper. All authors read and approved the final manuscript.

\section{Acknowledgements}

We are grateful to Dr. Xiao-Qiang Yu (Univ. of Missouri-Kansas City, U.S.A.) for his critical reading of the manuscript. This work was supported by the Sun Yat-sen University Research Program.

\section{Author details}

${ }^{1}$ State Key Laboratory of Biocontrol, School of Life Sciences, Sun Yat-sen University, Guangzhou 510275, China. ${ }^{2}$ State Key Laboratory of Respiratory Disease, Guangzhou Institute of Respiratory Disease, The First Affiliated Hospital of Guangzhou Medical College, Guangzhou 510230, China.

Received: 7 September 2012 Accepted: 14 May 2013

Published: 17 May 2013

\section{References}

1. Rajapakse N, Mendis E, Byun HG, Kim SK: Purification and in vitro antioxidative effects of giant squid muscle peptides on free radicalmediated oxidative systems. J Nutr Biochem 2005, 16(9):562-569.

2. Lee $K G$, Mitchell $A E$, Shibamoto T: Determination of antioxidant properties of aroma extracts from various beans. J Agric Food Chem 2000, 48(10):4817-4820.

3. Chen HM, Muramoto K, Yamauchi F: Structural analysis of antioxidative peptides from Soybean.beta.-Conglycinin. J Agric Food Chem 1995, 43(3):574-578.

4. Kim SY, Je JY, Kim SK: Purification and characterization of antioxidant peptide from hoki (Johnius belengerii) frame protein by gastrointestinal digestion. J Nutr Biochem 2007, 18(1):31-38.

5. Kim EK, Lee SJ, Jeon BT, Moon SH, Kim BK, Park TK, Han JS, Park PJ: Purification and characterisation of antioxidative peptides from enzymatic hydrolysates of venison protein. Food Chem 2009, 114(4):1365-1370.

6. Quaglia GB, Orban E: Influence of enzymatic hydrolysis on structure and emulsifying properties of sardine (Sardina pilchardus) protein hydrolysates. J Food Sci 1990, 55(6):1571-1573.

7. Tang CH, Wang XS, Yang XQ: Enzymatic hydrolysis of hemp (Cannabis sativa L.) protein isolate by various proteases and antioxidant properties of the resulting hydrolysates. Food Chem 2009, 114(4):1484-1490. 
8. Bougatef A, Hajji M, Balti R, Lassoued I, Triki-Ellouz Y, Nasri M: Antioxidant and free radical-scavenging activities of smooth hound (Mustelus mustelus) muscle protein hydrolysates obtained by gastrointestinal proteases. Food Chem 2009, 114(4):1198-1205.

9. Cumby N, Zhong Y, Naczk M, Shahidi F: Antioxidant activity and waterholding capacity of canola protein hydrolysates. Food Chem 2008, 109(1):144-148.

10. Thuong PT, Hung TM, Ngoc TM, Ha do T, Min BS, Kwack SJ, Kang TS, Choi JS, Bae K: Antioxidant activities of coumarins from Korean medicinal plants and their structure-activity relationships. Phytother Res 2010, 24(1):101-106.

11. Wu YB, Zheng $L J, W u$ JG, Chen TQ, Yi J, Wu JZ: Antioxidant activities of extract and fractions from receptaculum nelumbinis and related flavonol glycosides. Int J Mol Sci 2012, 13(6):7163-7173.

12. Zhou K, Sun S, Canning C: Production and functional characterisation of antioxidative hydrolysates from corn protein via enzymatic hydrolysis and ultrafiltration. Food Chem 2012, 135(3):1192-1197.

13. Zhang $Y$, Duan $X$, Zhuang $Y$ : Purification and characterization of novel antioxidant peptides from enzymatic hydrolysates of tilapia (Oreochromis niloticus) skin gelatin. Peptides 2012, 38(1):13-21.

14. Naqash SY, Nazeer RA: Optimization of enzymatic hydrolysis conditions for the production of antioxidant peptides from muscles of Nemipterus japonicus and Exocoetus volitans using response surface methodology. Amino Acids 2012, 43(1):337-345.

15. Ren J, Zhao M, Shi J, Wang J, Jiang Y, Cui C, Kakuda Y, Xue S: Purification and identification of antioxidant peptides from grass carp muscle hydrolysates by consecutive chromatography and electrospray ionization-mass spectrometry. Food Chem 2008, 108(2):727-736.

16. Rodriguez-Diaz JC, Kurozawa LE, Netto FM, Hubinger MD: Optimization of the enzymatic hydrolysis of Blue shark skin. J Food Sci 2011, 76(7):C938-C949.

17. You L, Regenstein JM, Liu RH: Optimization of hydrolysis conditions for the production of antioxidant peptides from fish gelatin using response surface methodology. J Food Sci 2010, 75(6):C582-C587.

18. Vercruysse L, Smagghe G, Beckers T, Camp JV: Antioxidative and ACE inhibitory activities in enzymatic hydrolysates of the cotton leafworm. Spodoptera littoralis. Food Chem 2009, 114(1):38-43.

19. Wang YS, Dang XL, Zheng XX, Wang J, Zhang WQ: Effect of extracted housefly pupae Peptide mixture on chilled pork preservation. J Food SCi 2010, 75(6):M383-M388.

20. Dang $X L$, Wang $Y S$, Huang YD, Yu XQ, Zhang WQ: Purification and characterization of an antimicrobial peptide, insect defensin, from immunized house fly (Diptera: Muscidae). J Med Entomol 2010, 47(6):1141-1145.

21. Pihlanto-Leppälä A: Bioactive peptides derived from bovine whey proteins: opioid and ace-inhibitory peptides. Trends Food Sci Tech 2000, 11(9-10):347-356.

22. Roberts PR, Burney JD, Black KW, Zaloga GP: Effect of chain length on absorption of biologically active peptides from the gastrointestinal tract. Digestion 1999, 60(4):332-337.

23. Saiga A, Tanabe $S$, Nishimura T: Antioxidant activity of peptides obtained from porcine myofibrillar proteins by protease treatment. $J$ Agric Food Chem 2003, 51(12):3661-3667.

24. Vijayalakshmi MA, Lemieux L, Amiot J: High performance size exclusion liquid chromatography of small molecular weight peptides from protein hydrolysates using methanol as a mobile phase additive. J Liq Chrom 1986, 9(16):3559-3576.

25. Yamaguchi T, Takamura H, Matoba T, Terao J: HPLC method for evaluation of the free radical-scavenging activity of foods by using 1,1-Diphenyl-2picrylhydrazyl. Biosci Biotechnol Biochem 1998, 62(6):1201-1204.

26. Rajapakse N, Mendis E, Jung WK, Je JY, Kim SK: Purification of a radical scavenging peptide from fermented mussel sauce and its antioxidant properties. Food Res Int 2005, 38(2):175-182.

27. Dreher D, Junod AF: Role of oxygen free radicals in cancer development. Eur J Cancer 1996, 32(1):30-38.

28. Li B, Chen F, Wang X, Ji B, Wu Y: Isolation and identification of antioxidative peptides from porcine collagen hydrolysate by consecutive chromatography and electrospray ionization-mass spectrometry. Food Chem 2007, 102(4):1135-1143.

29. Li Y, Jiang B, Zhang T, Mu WM, Liu J: Antioxidant and free radicalscavenging activities of chickpea protein hydrolysate (CPH). Food Chem 2008, 106(2):444-450.
30. Xie ZJ, Huang JR, Xu XM, Jin ZY: Antioxidant activity of peptides isolated from alfalfa leaf protein hydrolysate. Food Chem 2008, 111:370-376.

31. Cheng YH, Wang Z, Xu SY: Antioxidant properties of wheat germ protein hydrolysates evaluated in vitro. J Cent S Univ (Chinese, English Edition) 2006, 13(2):160-165.

32. Suetsuna $\mathrm{K}$, Ukeda $\mathrm{H}$, Ochi $\mathrm{H}$ : Isolation and characterization of free radical scavenging activities peptides derived from casein. J Nutr Biochem 2000, 11(3):128-131.

33. Tang $\mathrm{CH}$, Tang $\mathrm{CH}$, Ten Z, Wang XS, Yang XQ: Physicochemical and functional properties of hemp (Cannabis sativa L.) protein isolate. J Agric Food Chem 2006, 54(23):8945-8950.

34. Jun SY, Park PJ, Jung WK, Kim SK: Purification and characterization of an antioxidative peptide from enzymatic hydrolysate of yellowfin sole (Limanda aspera) frame protein. Eur Food Res Technol 2004, 219(1):20-26.

35. Halliwell B, Gutteridge JMC: Free radicals in biology and medicine. 3rd edition. Oxford: Oxford University Press; 1999.

36. Wang JS, Zhao MM, Zhao QZ, Jiang YM: Antioxidant properties of papain hydrolysates of wheat gluten in different oxidation systems. Food Chem 2007, 101(4):1658-1663.

37. Klompong V, Benjakul S, Kantachote D, Shahidi F: Antioxidative activity and functional properties of protein hydrolysate of yellow stripe trevally (Selaroides leptolepis) as influenced by the degree of hydrolysis and enzyme type. Food Chem 2007, 102(4):1317-1327.

38. Gbogouri GA, Linder M, Fanni J, Parmentier M: Influence of hydrolysis degree on the functional properties of salmon byproducts hydrolysates. J Food Sci 2004, 69(8):C615-C622.

39. Alder-Nissin J: Enzymatic hydrolysis of food protein. Amsterdam: Elsevier Applied Science Publishers; 1986.

40. Kristinsson HG, Rasco BA: Fish protein hydrolysates: production, biochemical, and functional properties. Crit Rev Food Sci Nutr 2000, 40(1):43-81.

41. APSnet: U.S. Pharmacopeia/National Formulary: [Available online, http://www. newdruginfo.com/pharmacopeia/]

42. Bhaskar N, Benila T, Radha C, Lalitha R: Optimization of enzymatic hydrolysis of visceral waste proteins of Catla (Catla catla) for preparing protein hydrolysate using a commercial protease. Bioresource Technol 2008, 99(2):335-343.

43. Schägger $H$, Von Jagow G: Tricine-sodium dodecyl sulfate-polyacrylamide gel electrophoresis for the separation of proteins in the range from 1 to 100 kDa. Analytical Biochem 1987, 166(2):368-379.

44. Yan JX, Wait R, Berkelman T, Harry RA, Westbrook JA, Wheeler CH, Dunn MJ: A modified silver staining protocol for visualization of proteins compatible with matrix-assisted laser desorption/ionization and electrospray ionization-mass spectrometry. Electrophoresis 2000, 21(17):3666-3672.

45. Shimada K, Fujikawa K, Yahara K, Nakamura T: Antioxidative properties of xanthan on the autoxidation of soybean oil in cyclodextrin emulsion. J Agric Food Chem 1992, 40(6):945-948.

46. Dinis TCP, Madeira VMC, Almeida LM: Action of phenolic derivatives (Acetaminophen, Salicylate, and 5-Aminosalicylate) as inhibitors of membrane lipid peroxidation and as peroxyl radical scavengers. Arch Biochem Biophys 1994, 315(1):161-169.

47. Mitsuda H, Yasumoto K, Iwami K: Antioxidative action of indole compounds during the autoxidation of linoleic acid. Eiyo to Shokuryo 1966, 19(3):210-214.

48. Yen GC, Hsieh CL: Antioxidant activity of extracts from Du-zhong (Eucommia ulmoides) toward various lipid peroxidation models in vitro. J Agric Food Chem 1998, 46(10):3952-3957.

49. Smirnoff $N$, Cumbes QJ: Hydroxyl radical scavenging activity of compatible solutes. Phytochem 1989, 28(4):1057-1060.

50. Marklund S, Marklund G: Involvement of the superoxide anion radical in the autoxidation of pyrogallol and a convenient assay for superoxide dismutase. Eur J Biochem 1974, 47(3):469-474.

51. Blackburn S: Amino Acids Determination-Methods and Techniques. 2nd edition. New York-Landon: Marcel Dekker, Inc.; 1978.

\section{doi:10.1186/1756-0500-6-197}

Cite this article as: Wang et al:: Housefly larvae hydrolysate: orthogonal optimization of hydrolysis, antioxidant activity, amino acid composition and functional properties. BMC Research Notes 2013 6:197. 